\title{
Anemia and Systemic Inflammation in Advanced Non-Small Cell Lung Cancer
}

\author{
Ileri Evre Küçük Hïcreli Dışı Akciğer Kanserinde Anemi ve Sistemik \\ Inflamasyon
}

\author{
Fisun Karadağ ${ }^{1}$, Şule T. Gülen ${ }^{1}$, Aslıhan B. Karul ${ }^{2}$ \\ ${ }^{1}$ Department of Chest Diseases, Faculty of Medicine, Adnan Menderes University, Aydin \\ ${ }^{2}$ Department of Biochemisty, Faculty of Medicine, Adnan Menderes University, Aydin
}

\begin{abstract}
Objective: We assessed hematological variables and various markers of systemic inflammation in a population of previously untreated patients with advanced non-small cell lung cancer (NSCLC) and healthy controls to evaluate the frequency of anemia and its correlation with systemic inflammation.

Methods: In patients with untreated advanced NSCLC and control subjects, levels of hemoglobin $(\mathrm{Hb})$, serum levels of acute phase reactants (APR) including C-reactive protein (CRP) and inflammatory cytokines (TNF- $\alpha$, leptin and osteopontin) were assessed. They were analysed by Pearson's correlation analysis and Mann-Whitney U test.
\end{abstract}

Results: Sixty-three male NSCLC patients with a mean age of 65.6 \pm 9.8 years were admitted to the study and 25 male healthy volunteers of the same age range were admitted as the control group. Twenty-five (40\%) NSCLC patients had anemia during diagnosis of lung carcinoma. Positive APR CRP, leucocyte, thrombocyte, ferritin and fibrinogen were higher in the NSCLC group than the controls ( $\mathrm{p}<0.001, \mathrm{p}=0.042, \mathrm{p}<0.001, \mathrm{p}=0.009, \mathrm{p}<0.001)$. Serum albumin (which is a negative APR) was lower in the cancer group $(\mathrm{p}<0.001)$. Osteopontin was higher in the cancer group $(p<0.001)$ but there were no difference in leptin and TNF- $\alpha$ concentrations. There was no correlation between $\mathrm{Hb}$ and stage of the disease, performance score of patients or cytokines. Serum CRP and thrombocyte concentrations were higher in cancer patients with anemia than those without anemia $(\mathrm{p}=0.012, \mathrm{p}<0.001)$. In the anemic subgroup of lung cancer patients, again $\mathrm{Hb}$ inversely correlated with CRP and thrombocyte and positively correlated with albumin

Conclusion: This evidence confirms that anemia is common in lung cancer and its presence is related to systemic inflammation.

Keywords: Acute phase reactants, anemia, C-reactive protein, cytokines, lung cancer, systemic inflammation

\section{ÖZET}

Amaç: Önceden tedavi görmemiş ileri evre küçük hücreli-dişı akciğer karsinomlu (KHDAK) bir grup hastada ve sağliklı kontrol grubunda anemi sıklığını ve sistemik inflamasyonla ilişkisini değerlendirmek için hematolojik değişkenleri ve çeşitli sistemik inflamasyon göstergelerini araştırdık.

Yöntemler: Henüz tedavi almamış KHDAK olguları ve kontrol gruplarında hemoglobin (Hb), C-reaktif protein (CRP) de dahil olmak üzere serum akut faz reaktanları (AFR) ve inflamatuvar sitokin (TNF- $\alpha$, leptin ve osteopontin) düzeyleri ölçüldü. Sonuçlar Pearson's korelasyon testi ve Mann-Whitney U tesi kullanılarak değerlendirildi.

Bulgular: Çalışmaya yaş ortalamaları $65,6 \pm 9,8$ yıl olan 63 erkek KHDAK olgusu dahil edildi. Aynı yaş grubunda olan 25 sağlıklı gönüllü kontrol grubu olarak alındi.Yirmi beş (\%40) KHDAK olgusunda tanı konduğu sırada anemi mevcut idi. Pozitif AFR olan CRP, lökosit, trombosit, ferritin ve fibrinojen düzeyleri KHDAK olgularında kontrol grubundan yüksekti $(\mathrm{p}<0,001, \mathrm{p}=0,042, \mathrm{p}<0,001$, $\mathrm{p}=0,009, \mathrm{p}<0,001)$. Serum albümini (negatif bir AFR) kanser grubunda daha düşüktü $(\mathrm{p}<0,001)$. Osteopontin kanser grubunda daha yüksek $(\mathrm{p}<0,001)$ iken leptin ve TNF- $\alpha$ konsantrasyonlarında fark yoktu. $\mathrm{Hb}$ ile hastalığın evresi, olguların performans skorları veya sitokinler arasında ilişki bulunmadi. Serum CRP ve trombosit konsantrasyonları anemisi olan kanser olgularında olmayanlara kıyasla daha yüksekti $(\mathrm{p}=0,012, \mathrm{p}<0,001)$. Anemik kanser olgularında yine $\mathrm{Hb}$; CRP ve trombosit ile ters, albümin ile doğru orantılı bulundu.

Sonuç: Bu bulgular aneminin akciğer kanserinde sık görüldüğünü ve sistemik inflamasyon ile ilişkili olduğunu doğrulamaktadır

Anahtar Kelimeler: Akut faz reaktanları, anemi, C-reaktif protein, sitokinler, akciğer kanseri, sistemik inflamasyon

Received date / Alındığı tarih: 23.01.2013; Accepted date / Kabul tarihi: 20.05.2013 Available online date / Çevrimiçi yayın tarihi: 20.09.2013

Address for correspondence / Yazışma adresi: Fisun Karadağ, Adnan Menderes Üniversitesi Tıp Fakültesi Hastanesi, Göğüs Hastalıkları Servisi, 09100 Aydın, Turkey; E-mail: fisunkaradag@yahoo.com

(C) Telif hakk1 2013 Türkiye Solunum Araştırmaları Derneği (TÜSAD) • (C) Copyright 2013 Turkish Respiratory Society (TRS)

Solunum 2013; 15(3):173-179 • DOI: 10.5152/solunum.2013.034

Makalelerin tam metinlerine www.solunum.org.tr/dergi adresinden ulaşabilirsiniz. • Available online at www.solunum.org.tr/dergi 


\section{INTRODUCTION}

Anemia is highly prevalent in patients with lung cancer, often occurring at baseline and frequently being exacerbated as a result of treatment with platinum-based chemotherapy (1). Anemia has been shown to have a negative effect on quality of life in patients with lung cancer, and additional data indicate that decreases in hemoglobin concentrations in these patients are associated with impaired survival $(2,3)$. Multiple clinical studies have demonstrated that treatment of anemia with erythropoietic agents in patients with lung cancer results in a significant increase in hemoglobin, decrease in transfusions, and improvement in quality of life $(4,5)$. Recognizing the extent and correlates of anemia in advanced cancer will be the first step towards improving its management in the future by targeted therapies.

The acute-phase response (APR) refers to a sequence of physiological changes in response to various stimuli, including tissue injury, infection, malignant growth and immunological disorders (6). The initiation and co-ordination of the APR is primarily regulated by cytokines, which operate in a complex network. Tumor necrosis factor-alpha (TNF- $\alpha$ ) and interleukin-1 (IL-1) are considered as proximal mediators within this network and they initiate a cascade of additional mediators such as interleukin-6 (IL-6). IL-6 is a major regulator of hepatic gene expression of APR (6). Conversion of the APR to chronic inflammation, i.e. in the course of neoplastic disorders, coincides with profound changes in iron metabolism and erythropoiesis frequently resulting in anemia, defined as anemia of chronic disease (ACD), or more recently referred to as anemia of inflammation (7). ACD is a mild to moderate anemia characterized by decreased serum iron, decreased total iron-binding capacity and increased iron stores (8).

Generally, the chronic anemia associated with cancer is characterized by an inadequate production of erythropoietin (EPO) for a given hemoglobin/hematocrit as well as an inadequate response of the erythroid marrow to endogenous EPO. In addition, there is impaired release of iron from stores as a result of increased hepcidin production so that, in chronic conditions, there is evidence of inadequate delivery of iron to the erythroid marrow and evidence of iron-deficient erythropoiesis (termed functional or relative iron deficiency). Finally, there is a mild shortening of red cell survival (7). The key to understanding the mechanisms surrounding these changes lies in the alterations in the production of several pro-inflammatory cytokines, including IL-1, IL-6, TNF- $\alpha$, the interferons (IFN) and hepcidin (7).

In the present study we assessed hematological variables and various markers of systemic inflammation (APR, TNF- $\alpha$, leptin and osteopontin) in a population of previously untreated patients with advanced non-small cell lung cancer (NSCLC) and healthy controls to evaluate the frequency of anemia and its correlation with systemic inflammation.

\section{METHODS}

\section{Subjects}

Sixty-three male lung cancer patients (age range 52-84 years) were admitted to the study consecutively. All patients were histopathologically confirmed to have NSCLC. Staging of the NSCLC patients was established by clinical findings, chest $\mathrm{x}$-ray, bronchoscopy, thorax CT, brain MRI and PET-CT on the basis of the latest TNM staging system (9). None of the patients had undergone surgical resection, or had received chemotherapy or radiotherapy at the time of sampling.

Twenty-five male volunteers of the same age range without cancer were admitted as the control group from the participants of the Chest Diseases Outpatients Clinic. Both patients and control subjects with comorbidities that may lead to anemia (chronic diseases, malnutrition) or systemic inflammation (infection, heart failure, collagen vascular diseases, etc.) were excluded from the study.

NSCLC patients were further divided into 2 subgroups as those having anemia $(\mathrm{Hb}<13 \mathrm{~g} / \mathrm{dL})(\mathrm{n}=25)$ or not $(\mathrm{n}=38)$. Anemia was defined according to World Health Organization criteria for men (10).

The study was approved by the ethics committee of Adnan Menderes University and all subjects gave written consent to participate in the study.

\section{Measurement of Acute Phase Reactants and Cytokines}

Fasting blood samples were collected for routine laboratory analysis of hematologic markers and acute phase reactants (APR). A further blood sample was taken and centrifuged at $4000 \mathrm{Xg}$ for $7 \mathrm{~min}$ at room temperature. The samples were stored in aliquots at $-80^{\circ} \mathrm{C}$ until analysis. Serum CRP concentration $(\mathrm{mg} / \mathrm{L})$ was measured by a commercially available kit by the turbidimetric method (Tokyo Boeiki, Prestige 24i, kit no: 81067 HWOO, Tokyo, Japan). Serum TNF- $\alpha$ concentration (pg/ $\mathrm{ml}$ ) was also measured by ELISA using hTNF- $\alpha$ kit (Bender MedSystems Human TNF- $\alpha$ kit no: BMS223INSTCE, Vienna, Austria). Serum leptin $(\mathrm{pg} / \mathrm{ml})$ concentrations were measured by solid phase sandwich enzyme-linked immunosorbant assay (ELISA) using (Bender MedSystems Human Leptin kit no: BMS2039INST, Vienna, Austria) according to the manufacturer's instructions. Serum osteopontin concentration (ng/dL) was measured by solid phase sandwich enzyme-linked immunosorbant assay (ELISA) using Assay Designs Human Osteopontin kit (Enzo Life Sciences, kit no: ADI-900-142, NY, USA) according to the manufacturer's instructions.

\section{Statistical Analysis}

Statistical tests were carried out with the SPSS software program. Results were presented as mean $\pm \mathrm{SD}$. Correlations between markers were evaluated using Pearson's correlation analysis. Non-parametric data of study groups were compared by Mann-Whitney $\mathrm{U}$ test. A significance level of $\mathrm{p}=0.05$ was used.

\section{RESULTS}

Sixty-three male lung cancer patients with a mean age of $65.6 \pm 9.8$ (age range 52-84) years were admitted to the study consecutively and 25 male volunteers of the same age (mean age of $63.5 \pm 11.5$ years) range without cancer were admitted as 
the control group. Demographic data of study groups and tumor characteristics of NSCLC patients admitted to the study are shown in Table 1. The subjects were all male and in the same age group. The smoking history of the groups was similar but the Karnofsky score was higher in the control group. Forty-three percent of NSCLC patients were classified as stage III and $57 \%$ as stage IV.

Twenty-five (40\%) of NSCLC patients had anemia during the diagnosis of lung carcinoma (before any treatment). Hemoglobin and serum Fe values were significantly lower and ferritin (which is also an APR) was higher in the lung cancer group; whereas there was no difference in iron binding capacity and transferrin (Table 2).

The positive acute phase reactants CRP, leucocyte, thrombocyte, ferritin and fibrinogen were higher in the lung cancer group than in controls. Serum albumin (which is a negative APR) was lower in the cancer group (Table 3). When cytokines were concerned, osteopontin was higher in the cancer group but there were no difference in serum leptin or TNF- $\alpha$ concentrations (Table 3).

The comparison of APR and cytokine (leptin, TNF- $\alpha$ and osteopontin) concentrations in lung cancer patients with or without anemia are shown in Table 4. Serum CRP and thrombocyte concentrations were higher and albumin was lower in cancer patients with anemia, whereas there was no difference in leucocyte, fibrinogen, ferritin and cytokine levels.

In correlation tests, $\mathrm{Hb}$ inversely correlated with $\mathrm{CRP}$ and thrombocyte levels in NSCLC patients (Table $\mathbf{5}$ and Figure 1). There was a positive correlation between $\mathrm{Hb}$ and albumin. However, there was no correlation between $\mathrm{Hb}$ and stage of the disease, performance score or cytokines (Table 5). In the anemic subgroup of NSCLC patients, again $\mathrm{Hb}$ negatively correlated with CRP $(\mathrm{p}=0,004 ; \mathrm{r}=-0,598)$ and thrombocyte $(\mathrm{p}=0,011 ; \mathrm{r}=-0,546)$ and positively correlated with albumin $(\mathrm{p}=0,001 ; \mathrm{r}=-0,656)$.

\section{DISCUSSION}

Anemia has been reported in association with lung cancer. Studies have reported its incidence as $50-60 \%$, which is much higher than that seen in colorectal and breast cancers (around $10-20 \%$ each) (11). After anticancer treatment, anemia was reported in $54 \%$ of patients and as many as $71 \%$ of patients were anemic at some time. However, anemia was treated in only $32 \%$ of patients (red blood cell transfusions, 61\%; iron supplementation, 33\%; while erythropoietin stimulating proteins in just $6 \%)(12)$. In our study, 25 (40\%) of patients with advanced lung cancer (stages III-IV) had anemia before anticancer treatment.

Anemia in the context of a malignancy predicts a poor outcome. It is associated with fatigue in 3 of every 4 cancer patients, as measured with the general version of the Functional Assessment of Cancer Therapy (FACT-G) questionnaire, and decreases the quality of life (QOL). In a telephone survey of 419 patients, $61 \%$ of cancer patients declared fatigue affected their daily lives more than pain (11). Weakness, shortness of
Table 1. Demographic data of study groups and tumor characteristics of NSCLC patients (mean \pm SD)

\begin{tabular}{lccc}
\hline \hline & $\begin{array}{c}\text { NSCLC } \\
(\mathbf{n = 6 3 )}\end{array}$ & $\begin{array}{c}\text { Controls } \\
(\mathbf{n = 2 5})\end{array}$ & P \\
\hline Age (year) & $65.6 \pm 9.8$ & $63.5 \pm 11.5$ & 0.063 \\
Gender M/F (\%) & $100 /-$ & $100 /-$ & - \\
Karnofsky score (\%) & 85 & 100 & $<0.001$ \\
Smoking (pack-year) & $63.8 \pm 30.2$ & $60.7 \pm 27.3$ & 0.079 \\
Stage, n (\%) & & & \\
IIla-IIlb & $27(43 \%)$ & - & - \\
IVa-IVb & $36(57 \%)$ & - & - \\
Histologic subtypes, n (\%) & & & - \\
Squamous cell & $11(17.5 \%)$ & - & \\
Adenocarcinoma & $15(23.8 \%)$ & - & \\
NSCLC (unspecified) & $37(58.7 \%)$ & - & \\
\hline
\end{tabular}

NSCLC: Non-small cell lung carcinoma

Table 2. Hematologic markers in NSCLC patients and controls (mean \pm SD)

\begin{tabular}{lccc}
\hline & $\begin{array}{c}\text { NSCLC patients } \\
(\mathbf{n = 6 3})\end{array}$ & $\begin{array}{c}\text { Controls } \\
(\mathbf{n = 2 5})\end{array}$ & P \\
\hline $\mathrm{Hb}(\mathrm{g} / \mathrm{dL})$ & $11.6 \pm 1.6$ & $14.9 \pm 1.4$ & $<0.001$ \\
$\mathrm{Fe}(\mu \mathrm{g} / \mathrm{dL})$ & $45.5 \pm 53.9$ & $90.4 \pm 57.2$ & $<0.001$ \\
Ferritin $(\mathrm{ng} / \mathrm{mL})$ & $252.5 \pm 212.4$ & $110.3 \pm 86.2$ & 0.009 \\
UIBC $(\mu \mathrm{g} / \mathrm{dL})$ & $224.9 \pm 84.7$ & $242.3 \pm 64.6$ & 0.248 \\
Transferrin $(\mathrm{ug} / \mathrm{dL})$ & $178.7 \pm 51.0$ & $190.0 \pm 38.2$ & 0.339 \\
\hline
\end{tabular}

Fe: Iron, Hb: Hemoglobin, NSCLC: Non-small cell lung carcinoma,

UIBC: Unsaturated iron binding capacity

Table 3. Serum acute phase reactants and cytokine levels in NSCLC patients and controls (mean \pm SD)

\begin{tabular}{lccc}
\hline & $\begin{array}{c}\text { NSCLC patients } \\
(\mathbf{n}=\mathbf{6 3})\end{array}$ & $\begin{array}{c}\text { Controls } \\
(\mathbf{n}=\mathbf{2 5})\end{array}$ & $\mathbf{P}$ \\
\hline Acute phase reactants & & & \\
CRP $(\mathrm{mg} / \mathrm{L})$ & $44.5 \pm 36.0$ & $6.1 \pm 14.9$ & $<0.001$ \\
Leucocyte $(\mathrm{mkrL})$ & $9815 \pm 3166$ & $8442 \pm 1923$ & 0.042 \\
Thrombocyte $(\mathrm{mkrL})$ & $368936 \pm 134528$ & $243952 \pm 104813$ & $<0.001$ \\
Fibrinogen $(\mathrm{mg} / \mathrm{dL})$ & $436.1 \pm 158.6$ & $240.0 \pm 93.2$ & $<0.001$ \\
Albumin $(\mathrm{g} / \mathrm{dL})$ & $4.2 \pm 0.4$ & $4.6 \pm 0.4$ & $<0.001$ \\
Ferritin $(\mathrm{ng} / \mathrm{mL})$ & $252.5 \pm 212.4$ & $110.3 \pm 86.2$ & 0.009 \\
Cytokines & & & \\
TNF- $\alpha(\mathrm{pg} / \mathrm{mL})$ & $5.6 \pm 2.1$ & $5.4 \pm 1.5$ & 0.063 \\
Leptin $(\mathrm{pg} / \mathrm{mL})$ & $187.4 \pm 98.1$ & $186.9 \pm 66.9$ & 0.528 \\
Osteopontin $(\mathrm{ng} / \mathrm{dL})$ & $3.3 \pm 3.2$ & $1.9 \pm 0.5$ & 0.001 \\
\hline
\end{tabular}

CRP: C-reactive protein, NSCLC: Non-small cell lung carcinoma, TNF- $\alpha$ : Tumor necrosis factor-alpha 
Table 4. Serum acute phase reactants and cytokine levels in NSCLC patients with or without anemia $\left(\right.$ mean $\left._{ \pm} \mathrm{SD}\right)$

\begin{tabular}{lccc}
\hline \hline & $\begin{array}{c}\text { NCSLC patients } \\
\text { with anemia } \\
(\mathbf{n}=\mathbf{2 5})\end{array}$ & $\begin{array}{c}\text { NCSLC patients } \\
\text { without anemia } \\
(\mathbf{n = 3 8})\end{array}$ & $\mathbf{P}$ \\
\hline Acute phase reactants & & & \\
CRP $(\mathrm{mg} / \mathrm{L})$ & $56.6 \pm 36.2$ & $36.6 \pm 34.1$ & 0.012 \\
Leucocyte $(\mathrm{mkrL})$ & $10220 \pm 3483$ & $9550 \pm 2958$ & 0.292 \\
Thrombocyte $(\mathrm{mkrL})$ & $435560 \pm 146804$ & $325105 \pm 106651$ & 0.001 \\
Fibrinogen (mg/dL) & $442.3 \pm 158.8$ & $428.3 \pm 137.5$ & 0.731 \\
Albumin (g/dL) & $4.1 \pm 0.5$ & $4.3 \pm 0.4$ & 0.015 \\
Ferritin $(\mathrm{ng} / \mathrm{mL})$ & $314.9 \pm 266.5$ & $213.5 \pm 163.0$ & 0.191 \\
Cytokines & & & \\
TNF- $\alpha(\mathrm{pg} / \mathrm{mL})$ & $5.7 \pm 1.1$ & $5.0 \pm 2.6$ & 0.527 \\
Leptin $(\mathrm{pg} / \mathrm{mL})$ & $192.8 \pm 97.8$ & $179.2 \pm 99.7$ & 0.710 \\
Osteopontin $(\mathrm{ng} / \mathrm{dL})$ & $3.4 \pm 3.3$ & $3.2 \pm 3.2$ & 0.518 \\
\hline
\end{tabular}

CRP: C-reactive protein, NSCLC: Non-small cell lung carcinoma, TNF- $\alpha$ : Tumor necrosis factor-alpha

Table 5. Correlates of anemia in NSCLC patients

\begin{tabular}{lcc}
\hline \hline $\mathbf{H b} \&$ & $\mathbf{p}$ & $\mathbf{r}$ \\
\hline Stage of cancer & 0.644 & -0.060 \\
Karnofsky score & 0.380 & 0.112 \\
CRP & 0.008 & -0.331 \\
Leucocyte & 0.955 & -0.007 \\
Thrombocyte & 0.001 & -0.405 \\
Fibrinogen & 0.759 & 0.043 \\
Ferritin & 0.206 & -0.178 \\
Albumin & 0.008 & 0.333 \\
TNF- $\alpha$ & 0.062 & -0.159 \\
Leptin & 0.175 & 0.201 \\
Osteopontin & 0.112 & -0.202 \\
\hline
\end{tabular}

CRP: C-reactive protein, $\mathrm{Hb}$ : Hemoglobin, NSCLC: Non-small cell lung carcinoma,

TNF- $\alpha$ : Tumor necrosis factor-alpha

breath, lightheadedness and dizziness were the other symptoms of anemia reported by cancer patients (13).

Anemia is also associated with a higher cancer recurrence rate and shorter survival after radiotherapy. This may reflect a more aggressive or extensive tumor burden, rather than a direct effect of the anemia itself, but there is some evidence that tumor-cell hypoxia, potentially exacerbated by anemia, may adversely affect radiosensitivity (11).

$\mathrm{Xu}$ et al. (2) investigated the impact of anemia on chemotherapy efficacy and prognosis in 140 patients with advanced non-small cell lung cancer and found that NSCLC patients had a higher incidence of anemia, especially the incidence of chemotherapy-related anemia. Age, clinical stage, performance score and albumin levels were the risk factors of pre-treatment

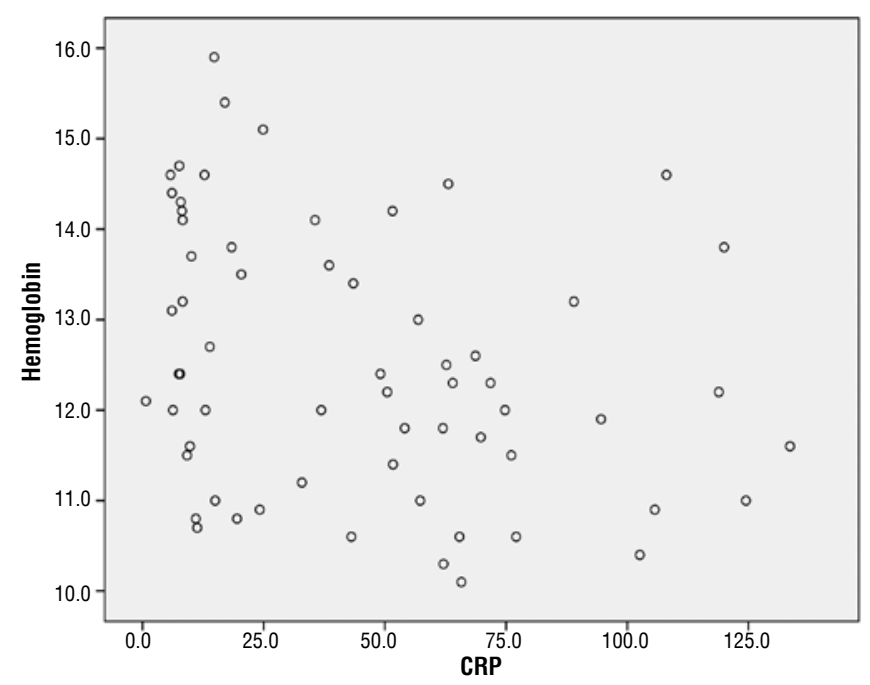

Figure 1. Correlation of $\mathrm{Hb}$ with CRP in NSCLC patients.

CRP: C-reactive protein, $\mathrm{Hb}$ : Hemoglobin, NSCLC: Non-small cell lung carcinoma

cancer-related anemia. NSCLC patients with anemia had lower QOL and chemotherapy efficacy, and shorter lifetime. Anemia was an independent prognostic factor in NSCLC patients. We did not find any correlation between $\mathrm{Hb}$ and stage of the disease or performance score in our study, but that may be because we did not have any stage I or II patients; they were all stage III or IV.

Anemia of chronic disease is believed to be the major underlying cause of anemia in cancer patients. However, platinum-based chemotherapy is also an important factor and may at least partially explain why lung cancer has one of the highest rates of anemia among the common malignancies (11). That was why we evaluated the patients before any anticancer treatment.

Cancer related anemia (CRA) is typically normochromic, normocytic with a low reticulocyte count. Bone marrow iron stores are adequate or increased, but iron reutilization is impaired, as shown by normal or increased ferritin levels and low serum iron levels and iron binding capacity (14). In CRA, erythroid progenitor cells respond normally to erythropoietin (EPO), but EPO production is often not optimal for the level of anemia. The biologic and hematologic characteristics of CRA are similar to those observed in anemia occurring in chronic inflammatory diseases (14). Similarly, we detected that hemoglobin and serum Fe values were significantly lower and ferritin (which is also an APR) was higher in the lung cancer group; whereas there was no difference in iron binding capacity and transferrin.

Several studies showed that proinflammatory cytokines blunt the EPO response to anemia and impair erythroid colony formation in response to EPO. Additionally, proinflammatory cytokines IL-1, IL-6, TNF- $\alpha$, and the acute-phase proteins impair iron metabolism, inhibiting the reticuloendothelial iron stores with low iron circulating levels. Disorder in iron reutilization also characterizes CRA (14).

Markers of chronic inflammation commonly observed in patients with malignancy, are thought to relate to the stage of disease, to low performance status (PS), and to compromised nutritional status and weight loss (15). Inflammatory mediators, 
particularly cytokines IL- 6 , TNF- $\alpha$, and IL- $1 \beta$ have been recognized to play a key role in inducing anorexia, nausea/vomiting, and the severe energy metabolism disorders occurring in patients with advanced cancer. The release of proinflammatory cytokines in neoplastic patients is often associated with increased production of reactive oxygen species (ROS) either as a component of their immune response or as a consequence of increased metabolism (15). Thus, the presence of inflammation in patients with cancer may account for profound physiologic changes, including those metabolic changes resulting in cachexia and, possibly, anemia. Several in vitro and in vivo studies demonstrated that high levels of proinflammatory cytokines and increased oxidative stress contribute both to the development of anemia and to the resistance to recombinant human EPO (16).

Experimental data on mice and human indicate that that IL-6 causes anemia independent of a reduction in EPO levels $(17,18)$. When recombinant human interleukin-6 (rhlL-6) was administered to lung cancer patients, a reversible anemia, characterized by a decrease in serum iron, and an increase in ferritin and erythropoietin without reticulocytosis, developed. Also a dose-related increase of CRP plasma levels was observed (18). In our study, the positive acute phase reactants CRP, leucocyte, thrombocyte and fibrinogen were higher in the NSCLC group than controls. $\mathrm{Hb}$ inversely correlated with CRP in NSCLC patients. In the anemic subgroup of NSCLC patients, $\mathrm{Hb}$ was again negatively correlated with CRP.

TNF is a pleiotropic cytokine with activities that extend beyond its antitumour effect. There is now increasing evidence that TNF can be either constitutively produced or induced in human tumors. Tumor cells may also lead to TNF induction in normal cells. Its effects range from stimulation of cancer growth and metastasis, to metabolic and haematological disturbances, e.g. cancer cachexia, anaemia, and hypercalcaemia (19).

Feelders et al. (6) examined the prolonged effects of isolated limb perfusion (ILP) with recombinant human tumour necrosis factor alpha (rTNF) on IL-6 and acute-phase protein levels, iron status and serum transferrin receptor (sTfR) levels in 12 cancer patients and reported that after ILP, leakage of TNF resulted in peak systemic levels at 3 min followed by an increase in IL- 6 with maximum levels at $4 \mathrm{~h}$. CRP rose at $4 \mathrm{~h}$ to peak levels at day 2 . Albumin and transferrin levels decreased after ILP and recovered after day 2 . Serum iron and sTfR levels decreased during pretreatment and after ILP to minimum levels at $8 \mathrm{~h}$ and day 1 respectively. This was associated with an increase in serum ferritin levels, which paralleled CRP values. Their data pointed to a central role for the cytokine network in the modulation of iron metabolism in the acute-phase response and anemia of chronic disease. TNF, possibly via induction of IL-6, and IFN- $\gamma$, induces hypoferraemia, which may in part result from a decrease in tissue iron release based on a primary stimulation of ferritin synthesis. The fall in sTfR levels may reflect an impaired erythroid growth and/or TfR expression mediated by TNF and IFN- $\gamma(6)$. In the present study, we did not find any difference in serum TNF- $\alpha$ concentrations of the patients with or without cancer. In most clinical conditions TNF- $\alpha$ is only transiently elevated in serum and therefore a single blood sampling may not reflect the chronic state (20).
Ferritin is an ubiquitous intracellular protein that stores iron and releases it in a controlled fashion. The increase in the serum ferritin actually has two components: reflecting the increase in iron stores and in response to the general inflammatory process, itself, since ferritin is an acute phase reactant (21). If ferritin is high, there is iron in excess or else there is an acute inflammatory reaction in which ferritin is mobilized without iron excess. Kukulj et al. (22) investigated altered iron metabolism, inflammation, transferrin receptors, and ferritin expression in non-small-cell lung cancer and found that at the time of diagnosis, more than half of the patients had anemia and significantly elevated serum ferritin. Iron content of serum ferritin (ICF) was below the reference values in $90 \%$ of patients. Furthermore, ICF showed positive correlation with iron metabolic markers and survival but negative correlation with serum ferritin and ESR. Tumor tissue ferritin expression showed a negative correlation with serum iron and hematocrit $(\mathrm{Ht})$, and positive correlation with ferritin, erythrocyte sedimentation rate (ESR), alpha-1 globulin, and alpha-2 globulin. They concluded that elevated serum ferritin in sera of NSCLC patients is the result of inflammation and oxidative stress rather than body iron overload. Ferritin, as an APR, was higher in the lung cancer group than the controls in our study.

Leptin, the product of the ob gene, is a protein synthesized and secreted mainly by white adipose tissue in proportion to fat stores, and it is considered as an adipokine which belongs to the class I cytokine superfamily $(23,24)$. Leptin expression is upregulated by various proinflammatory cytokines, including TNF- $\alpha$, IL-1, IL-6 (25). However, in contrast to acute stimulation of the inflammatory system, chronic inflammation causes a reduction in leptin levels (26). Leptin has emerged in the literature as a multifunctional hormone with versatile activities and complex counteractions with other cytokines and adipokines (24). A remarkable aspect of the effects of leptin on the immune system is its action as a proinflammatory cytokine itself. Leptin can therefore be described as a cytokine-like hormone with pleiotropic actions (23). Although we did not detect a relationship with other inflammatory markers, we previously found that leptin was lower in weight-losing cancer patients (27). The role of leptin in anemia of chronic disease has not yet been extensively studied. A polymorphism in the leptin gene promoter was found to be associated with anemia in patients with HIV disease (28). Chung et al. (29) reported that leptin increases the expression of the iron regulatory hormone hepcidin in $\mathrm{HuH} 7$ human hepatoma cells. These data suggest that leptin upregulates hepatic hepcidin expression. As a consequence, the increased production of leptin in overweight individuals might be a major contributor to the aberrant iron status observed in these population groups. In the present study, we did not find any difference in serum leptin levels of patients with or without lung cancer and did not detect any relation with markers of anemia.

Osteopontin (OPN) is a multifunctional protein classified as both a matricellular protein and a cytokine. Data from experimental studies suggest that OPN is induced during malignant 
transformation and may function in tumorigenesis or regulate development of a metastatic phenotype (30). Clinical studies also revealed that elevated concentrations of OPN are associated with advanced stages of lung carcinoma, increased risk of lymph node metastasis, and shorter overall survival even in early stages (31). OPN is currently being studied as a potential biomarker for cancer and there is interest in targeting OPN as a therapeutic treatment for cancer (32).

With its well-characterized cytokine-like properties, OPN is known to have multiple functions in the inflammatory cascade (30). Although the role of OPN in tumorigenesis and invasiveness is well-known, its role in the systemic consequences of lung cancer like cancer related anemia or anemia of inflammation has not been studied as far as we know. Previously, we have found a positive correlation between OPN and CRP and considered $\mathrm{OPN}$ as an indicator of systemic inflammation in lung cancer patients (33). In the present study, serum level of osteopontin was higher in the cancer group but neither was there a difference in lung cancer patients with or without anemia nor a relation with markers of anemia.

Anemia affects the health-related quality of life and impacts the prognosis and outcome of therapy. Despite this clinical relevance, anemia is often underrecognized and undertreated. Treatment options include the administration of hematopoietic growth factors and red blood cell transfusions. Blood transfusions result in rapid but often transient improvement of anemia. Administration of epoetin or darbepoetin alfa increases hemoglobin levels, decreases blood transfusions, and improves the quality of life in patients with lung cancer (5). Trials determining the exact association of anemia with response to chemotherapy/radiation therapy and survival are ongoing. Oncologists must be aware of the clinical relevance of anemia and offer adequate treatment options to their patients.

\section{CONCLUSION}

The results of the present study reveal that anemia is common in advanced lung cancer. The correlation between hemoglobin levels and elevated markers of inflammation suggest that the systemic inflammation is, at least partially, responsible for anemia in lung cancer patients.

\section{Conflict of Interest}

No conflict of interest was declared by the authors.

Peer-review: Externally peer-reviewed.

Ethics Committee Approval: Ethics committee approval for this study was received from the ethics committee of Adnan Menderes University.

Informed Consent: Written informed consent was obtained from patients who participated in this study.

\section{Author Contributions}

Concept - F.K.; Design - F.K.; Supervision - F.K.; Funding - F.K., S..T.G.; Materials - Ş.T.G.; A.B.K.; Data Collection and/or Processing - S.T.G.; A.B.K.; Analysis and/or Interpretation - F.K.; A.B.K.; Literature Review - F.K.; Writing - F.K.; Critical Review- A.B.K.

\section{Çıkar Çatışması}

Yazarlar herhangi bir çıkar çatışması bildirmemişlerdir.

Hakem değerlendirmesi: Dış bağımsız.

Etik Komite Onayı: Bu çalışma için etik komite onayı Adnan Menderes Üniversitesi Yerel Etik Kurulu'ndan alınmıştır.

Hasta Onamı: Bu çalışmaya katılan hastalardan yazılı hasta ona$\mathrm{m} ı$ alınmıştır.

\section{Yazar Katkıları}

Fikir - F.K.; Tasarım - F.K.; Denetleme - F.K.; Kaynaklar - F.K., Ş.T.G.; Malzemeler - A.B.K.; Veri toplanması ve/veya işlemesi - Ş.T.G., A.B.K.; Analiz ve/veya yorum - F.K., A.B.K.; Literatür taraması - F.K.; Yazıyı yazan - F.K.; Eleştirel İnceleme - A.B.K.

\section{REFERENCES}

1. Crawford J, Kosmidis PA, Hirsch FR, Langer CJ. Targeting anemia in patients with lung cancer. J Thorac Oncol 2006; 1: 716-25. [CrossRef]

2. Xu C, Gao Y, Li L, Xing L, Liu S. Impact of anemia on chemotherapy efficacy and prognosis in patients with advanced non-small cell lung cancer. Zhongguo Fei Ai Za Zhi 2010; 13: 968-74.

3. Tomita M, Shimizu T, Hara M, Ayabe T, Onitsuka T. Preoperative leukocytosis, anemia and thrombocytosis are associated with poor survival in non-small cell lung cancer. Anticancer Res 2009; 29: 2687-90.

4. Crawford J, Robert F, Perry MC, Belani C, Williams D; Anemia Prevention in NSCLC Group. A randomized trial comparing immediate versus delayed treatment of anemia with once-weekly epoetin alfa in patients with non-small cell lung cancer scheduled to receive first-line chemotherapy. J Thorac Oncol 2007; 2: 210-20. [CrossRef]

5. Pirker R, Wiesenberger K, Pohl G, Minar W. Anemia in lung cancer: clinical impact and management. Clin Lung Cancer 2003; 5: 90-7. [CrossRef]

6. Feelders RA, Vreugdenhil G, Eggermont AM, Kuiper-Kramer PA, van Eijk HG, Swaak AJ. Regulation of iron metabolism in the acute-phase response: interferon gamma and tumour necrosis factor alpha induce hypoferraemia, ferritin production and a decrease in circulating transferrin receptors in cancer patients. Eur J Clin Invest 1998; 28: 520-7. [CrossRef]

7. Adamson JW. The anemia of inflammation/malignancy: mechanisms and management. Hematology 2008; Am Soc Hematol Educ Program 2008: 159-65.

8. Bertero MT, Caligaris-Cappio F. Anemia of chronic disorders in systemic autoimmune diseases. Haematologica 1997; 82: 375-81.

9. Detterbeck FC, Boffa DJ, Tanoue LT. The New Lung Cancer Staging System. Chest 2009; 136: 260-71. [CrossRef]

10. WHO. Haemoglobin concentrations for the diagnosis of anaemia and assessment of severity. Vitamin and Mineral Nutrition Information System. Geneva, World Health Organization (WHO/NMH/ NHD/MNM/11.1) 2011. http://www.who.int/vmnis/indicators/ haemoglobin.pdf, accessed 5.1.2012. 
11. Shafiq M, Venkateshiah S. Hematologic Abnormalities Associated With Lung Carcinoma. Respir Care 2011; 56: 523-6. [CrossRef]

12. Wojtukiewicz MZ, Sierko E, Rybaltowski M, Filipczyk-Cisarz E, Staroslawska E, Tujakowski J, et al. The Polish Cancer Anemia Survey (POLCAS): a retrospective multicenter study of 999 cases. Int J Hematol 2009; 89: 276-84. [CrossRef]

13. Kleinman L, Benjamin K, Viswanathan H, Mattera MS, Bosserman L, Blayney DW, et al. The anemia impact measure (AIM): development and content validation of a patient-reported outcome measure of anemia symptoms and symptom impacts in cancer patients receiving chemotherapy. Qual Life Res 2012; 21: 1255-66. [CrossRef]

14. Macciò A, Madeddu C, Massa D, Mudu MC, Lusso MR, Gramignano $\mathrm{G}$, et al. Hemoglobin levels correlate with interleukin-6 levels in patients with advanced untreated epithelial ovarian cancer: role of inflammation in cancer-related anemia. Blood 2005; 106: 362-7. [CrossRef]

15. Mantovani G, Maccio`A, Madeddu C, Mura L, Gramignano G, Lusso $\mathrm{MR}$, et al. Quantitative evaluation of oxidative stress, chronic inflammatory indices and leptin in cancer patients: correlation with stage and performance status. Int J Cancer 2002; 98: 84-91. [CrossRef]

16. Means RT Jr. The anemia of infection. Baillieres Best Pract Res Clin Haematol 2000; 13: 151-62. [CrossRef]

17. Mori K, Fujimoto-Ouchi K, Onuma E, Noguchi M, Shimonaka Y, Yasuno $\mathrm{H}$, et al. Novel models of cancer-related anemia in mice inoculated with IL-6-producing tumor cells. Biomed Res 2009; 30: 47-51. [CrossRef]

18. van Gameren MM, Willemse PH, Mulder NH, Limburg PC, Groen HJ, Vellenga E, et al. Effects of recombinant human interleukin-6 in cancer patients: a phase I-II study. Blood 1994; 84: 1434-41.

19. Malik ST. Tumour necrosis factor: roles in cancer pathophysiology. Semin Cancer Biol 1992; 3: 27-33.

20. Tracey KJ, Cerami A. Tumor necrosis factor, other cytokines, and disease. Annu Rev Cell Biol 1993; 9: 317-43. [CrossRef]

21. Elin RJ, Wolff SM, Finch CA. Effect of induced fever on serum iron and ferritin concentrations in man. Blood 1977; 49: 147-53.
22. Kukulj S, Jaganjac M, Boranic M, Krizanac S, Santic Z, Poljak-Blazi M. Altered iron metabolism, inflammation, transferrin receptors, and ferritin expression in non-small-cell lung cancer. Med Oncol 2010; 27: 268-77. [CrossRef]

23. Lago F, Dieguez C, Gómez-Reino J, Gualillo O. Adipokines as emerging mediators of immune response and inflammation. Nat Clin Pract Rheumatol 2007; 3: 716-24. [CrossRef]

24. Malli F, Papaioannou AI, Gourgoulianis KI, Daniil Z. The role of leptin in the respiratory system: an overview. Respir Res 2010; 11: 152-68. [CrossRef]

25. Otero M, Lago R, Lago F, Casanueva FF, Dieguez C, Gómez-Reino $\mathrm{JJ}$, et al. Leptin, from fat to inflammation: old questions and new insights. FEBS Lett 2005; 579: 295-301. [CrossRef]

26. Popa C, Netea MG, Radstake TR, van Riel PL, Barrera P, van der Meer JW. Markers of inflammation are negatively correlated with serum leptin in rheumatoid arthritis. Ann Rheum Dis 2005; 64: 1195-8. [CrossRef]

27. Gulen ST, Karadag F, Karul AB, Kilicarslan N, Ceylan E, Kuman $\mathrm{NK}$, et al. Adipokines and systemic inflammation in weight-loosing lung cancer patients. Lung 2012; 190: 327-32. [CrossRef]

28. Vanasse GJ, Jeong JY, Tate J, Bathulapalli H, Anderson D, Steen H, et al. A polymorphism in the leptin gene promoter is associated with anemia in patients with HIV disease. Blood 2011; 118: 5401-8. [CrossRef]

29. Chung B, Matak P, McKie AT, Sharp P. Leptin increases the expression of the iron regulatory hormone hepcidin in $\mathrm{HuH7}$ human hepatoma cells. J Nutr 2007; 137: 2366-70.

30. O'Regan A. The Role of osteopontin in lung disease. Cytokine Growth Factor Rev 2003; 14: 479-88. [CrossRef]

31. Chang YS, Kim HJ, Chang J, Ahn CM, Kim SK. Elevated circulating level of osteopontin is associated with advanced disease state of nonsmall cell lung cancer. Lung Cancer 2007; 57: 373-80. [CrossRef]

32. Lund SA, Giachelli CM. The role of osteopontin in inflammatory processes. J Cell Commun Signal 2009; 3: 311-22. [CrossRef]

33. Karadag F, Gulen ST, Karul AB, Kilicarslan N, Ceylan E, Kuman $\mathrm{NK}$, et al. Osteopontin as a marker of weight loss in lung cancer. Scand J Clin Lab Invest 2011; 71: 690-4. [CrossRef] 